dr inż. Krzysztof Bizoń

Politechnika Ślaska

\title{
Zastosowanie metod magnetycznych do oceny stopnia degradacji zmęczeniowej staliwa LII500 na przykładzie kół napędnych lokomotywy EU07
}

\begin{abstract}
$W$ artykule przedstawiono wyniki pomiarów wartości wybranych własności magnetycznych materiatu (staliwo LII500) do oceny stopnia jego degradacji zmęczeniowej, na przykładzie koła napędnego lokomotywy EU07. Zakres badań obejmowat badania wlasności magnetycznych materiatu obiektu rzeczywistego oraz badania laboratoryjne własności magnetycznych próbek materiału koła. Badaniom laboratoryjnym poddano próbki materiatu koła pozyskane z obszarów o mniejszym $i$ większym stopniu degradacji zmęczeniowej. Badania obiektu rzeczywistego polegaty na pomiarze dynamicznej pętli histerezy magnetycznej $w$ wybranych punktach na wewnętrznej i zewnętrznej powierzchni tarczy koła. Metodę pomiaru dynamicznej pętli histerezy magnetycznej oparto na zasadzie pomiaru wartości indukcji magnetycznej $w$ szczelinie powietrznej obwodu magnetycznego, w którym jarzmo z uzwojeniem magnesuje badany materiat. Do pomiaru wartości indukcji magnetycznej (wyrażonej wartościq napięcia) wykorzystano hallotron. Wykonano barwne mapy rozkładu zmierzonych wartości parametrów magnetycznych. Dokonano również pomiarów sonda działajaca na zasadzie sondy Foerstera. Uzyskano barwna mape rozkładu parametru opisujacego zmiane indukcyjności sondy pomiarowej $w$ zależności od miejsca pomiaru na wewnętrznej powierzchni tarczy koła.
\end{abstract}

\section{Wstęp}

Remont układu napędnego lokomotywy EU07 polega na jego całkowitym demontażu i przeprowadzeniu badań defektoskopowych kół napędnych metodą wizualną i penetracyjną barwna. Badania te mają na celu wykrycie pęknięć w kole napędnym (rys.1.). Pęknięcie eliminuje koło z dalszej eksploatacji. Metoda wizualna i metoda penetracyjna barwna są metodami prostymi, szybkimi i skutecznymi w wykrywaniu już istniejących pęknięć kół kolejowych. Nie są one jednak w stanie wykryć miejsc w kole napędnym o strukturze na tyle zdegradowanej, że w krótkim okresie czasu od badania wystąpi w nim pęknięcie.

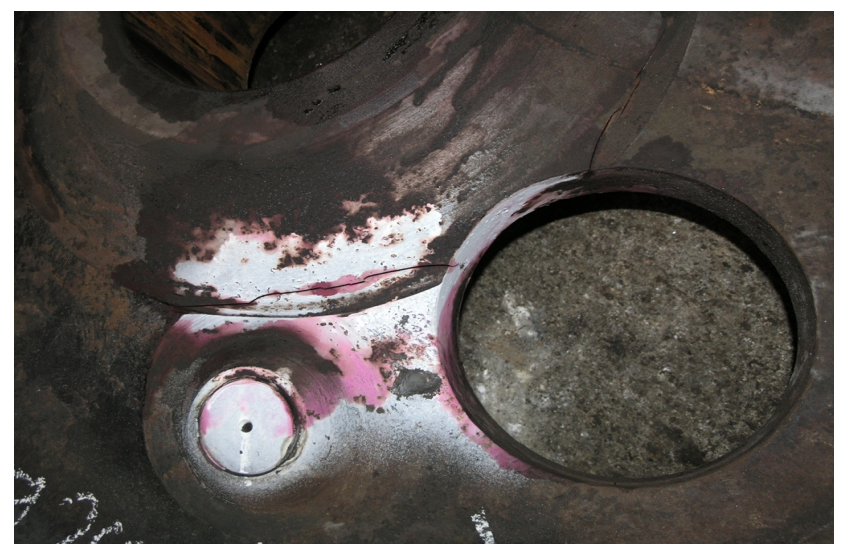

Rys.1. Pęknięcie koła napędowego lokomotywy EU07 wykryte metodą penetracyjną barwną. 
Pęknięcia kół napędnych charakteryzuje wysoka powtarzalność miejsc ich powstawania (rys.2.). Przyczyny powstawania pęknięć w tego typu kołach nie są w pełni zidentyfikowane. Symulacje komputerowe prowadzone $\mathrm{z}$ wykorzystaniem metody elementów skończonych wykazały, że w materiale koła nie następuje przekroczenie dopuszczalnej wartości naprężeń [1]. Można jednak stwierdzić, iż podczas toczenia się po szynach, koła są poddane cyklicznym, sinusoidalnym niesymetrycznym obciążeniom. Obciążenia o takim charakterze mogą być przyczyną zmęczeniowego pękania materiału koła [1].

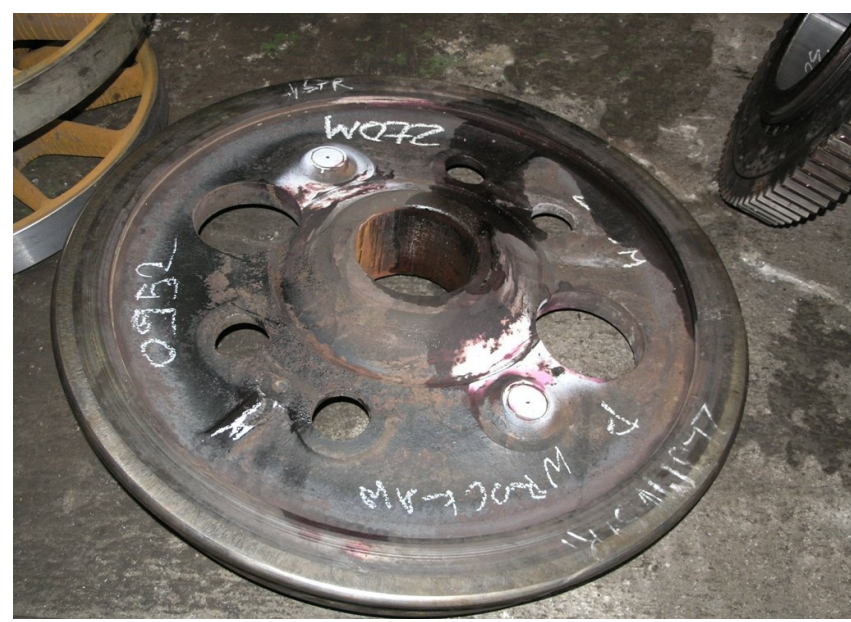

Rys.2. Koło napędne lokomotywy EU07 z zaznaczonymi miejscami pęknięć.

\section{Teoretyczne uzasadnienie podjętych badań}

Staliwo LII500 jest podstawowym materiałem stosowanym do produkcji napędnych kół kolejowych lokomotyw EU07. Stopy żelaza z węglem (w tym również staliwa) w większości przypadków mogą być poddawane badaniom diagnostycznym magnetycznym. Wpływ naprężeń mechanicznych, wywołanych czynnikami zewnętrznymi (kształtowanie materiału, obróbka cieplna, obciążenia eksploatacyjne) na parametry magnetyczne materiału nie jest jednakowy dla wszystkich gatunków stali i staliw. Każdy gatunek stali bądź staliwa wymaga niezależnych badań zmienności parametrów magnetycznych od czynników zewnętrznych pod kątem możliwości zastosowania diagnostyki magnetycznej. Wielkościami fizycznymi magnetycznymi, czułymi na strukturę materiału są przede wszystkim: dynamiczna przenikalność magnetyczna oraz tangens kąta stratności. Wpływ procesów degradacyjnych materiału na zmiany parametrów magnetycznych każdego gatunku stali bądź staliwa (ferromagnetyka) przebiega w sposób charakterystyczny i indywidualny, zależny między innymi od składu chemicznego materiału i od charakteru obciążeń zmęczeniowych [2-5].

\section{Obliczenia wytrzymałościowe metodą elemen- tów skończonych}

Symulacje komputerowe prowadzone z wykorzystaniem metody elementów skończonych wykazały, że w materiale koła nie następuje przekroczenie dopuszczalnej wartości naprężeń [1]. Można jednak stwierdzić, iż podczas toczenia się po szynach, koła są poddane cyklicznym, sinusoidalnym niesymetrycznym obciążeniom. Obciążenia o takim charakterze mogą być przyczyną zmęczeniowego pękania materiału koła [1]. Symulacje komputerowe przeprowadzono wykorzystując program Ansys Workbench. Warunki brzegowe (podparcia i obciążenia) modelu dyskretnego (rys.4.) przyjęto zgodnie $\mathrm{z}$ obowiązującymi normami $[6,7]$ i wcześniejszymi pracami prowadzonymi w Katedrze Transportu Szynowego $[6,7]$. Uwzględniono obciążenia od wcisku koła na oś zestawu kołowego (poprzez zdefiniowanie wstępnego przemieszczenia węzłów elementów skończonych na wewnętrznej powierzchni piasty koła), obciążenia od wzajemnego oddziaływania koła i szyny w postaci sił skupionych dla różnych przypadków ruchu koła po szynie (jazda po prostym odcinku toru, jazda po łuku toru), obciążenia od układu napędowego (rys.3.). Wykonano obliczenia wytrzymałościowe dla różnych punktów przyłożenia sił oddziaływania pomiędzy szyną i kołem zmieniając punkt przyłożenia sił po obwodzie koła symulując w ten sposób toczenie się koła po szynie.
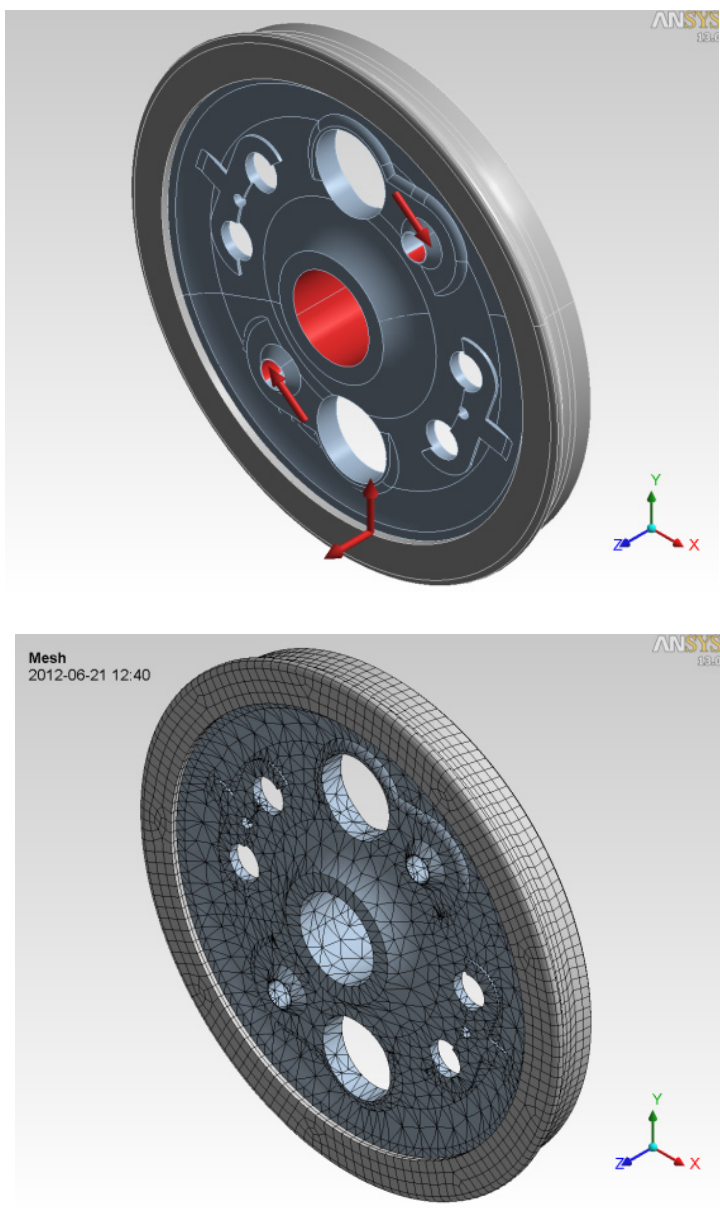

Rys.3. Schemat obciążenia i model dyskretny koła napędnego lokomotywy EU07. 
a)

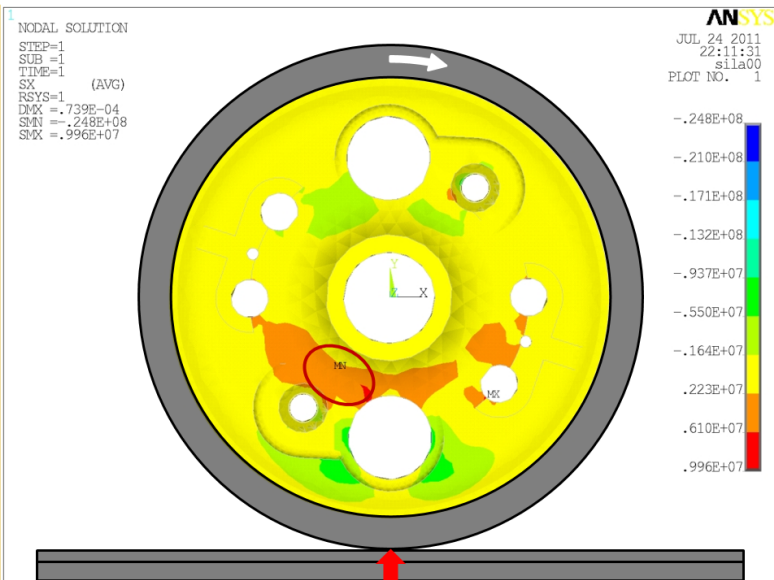

c)

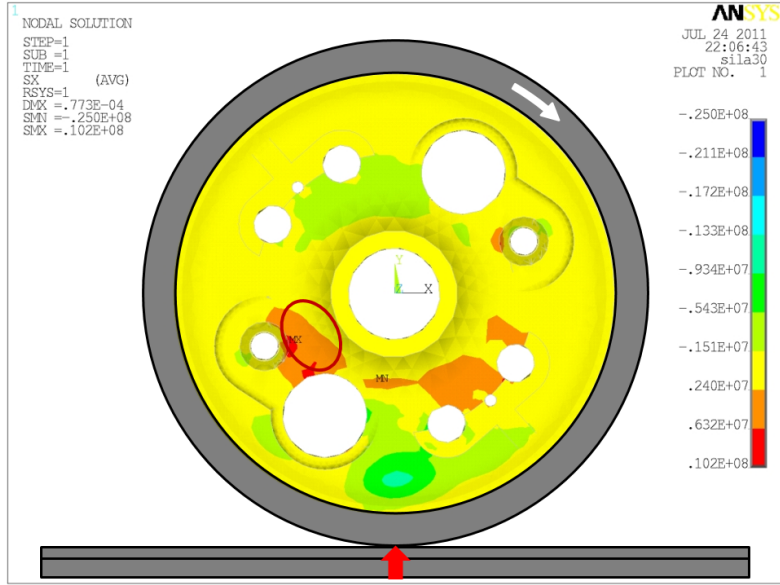

e)

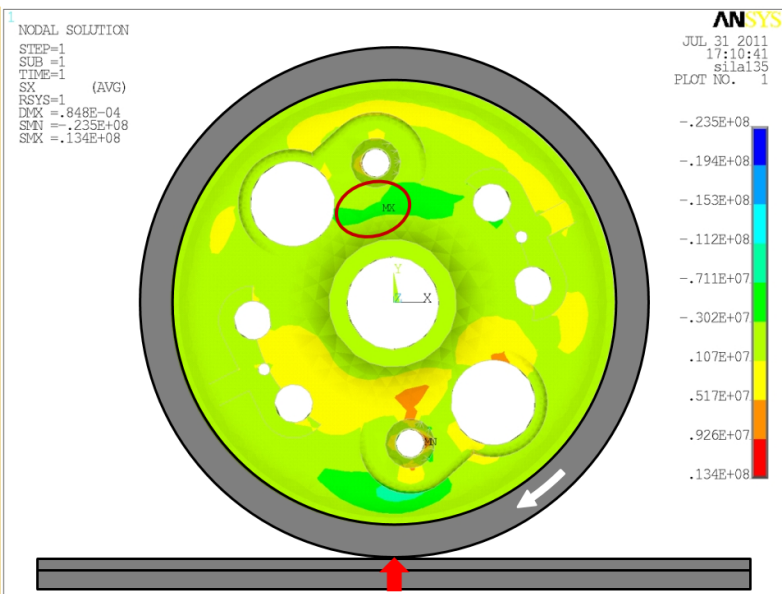

b)

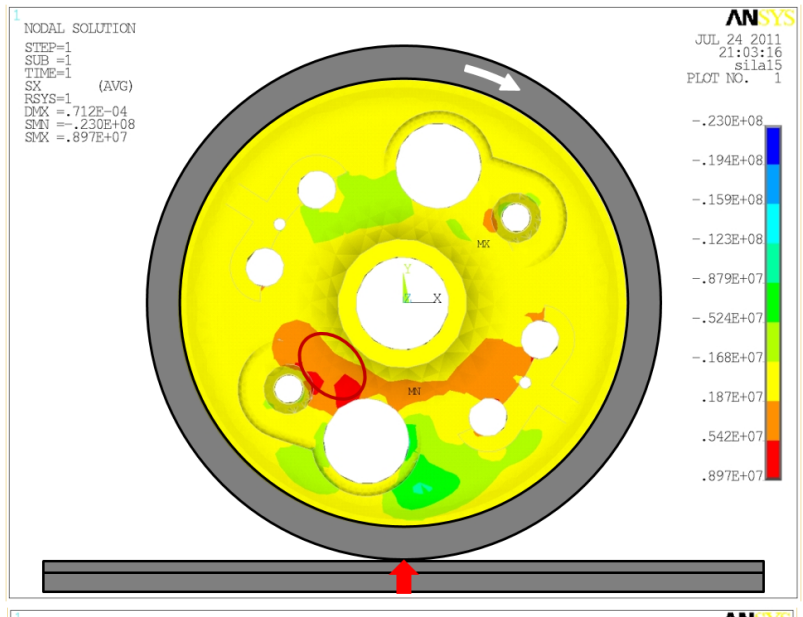

d)

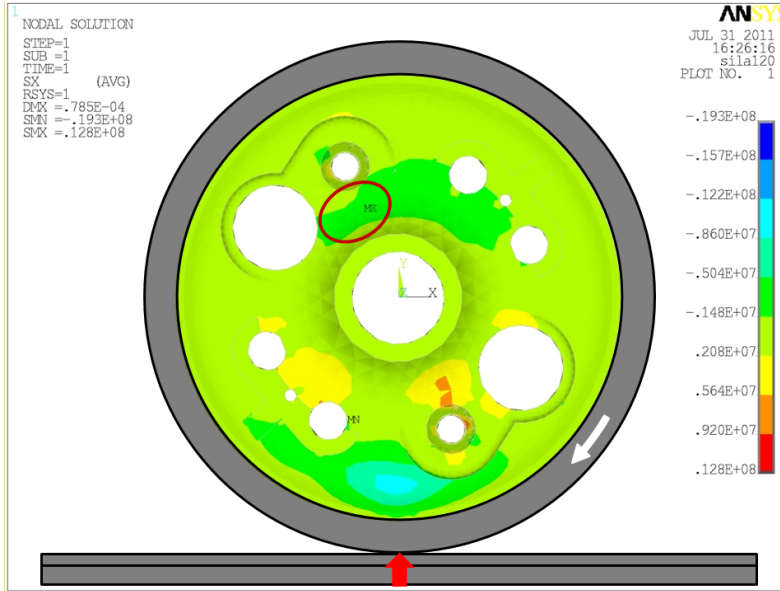

f)

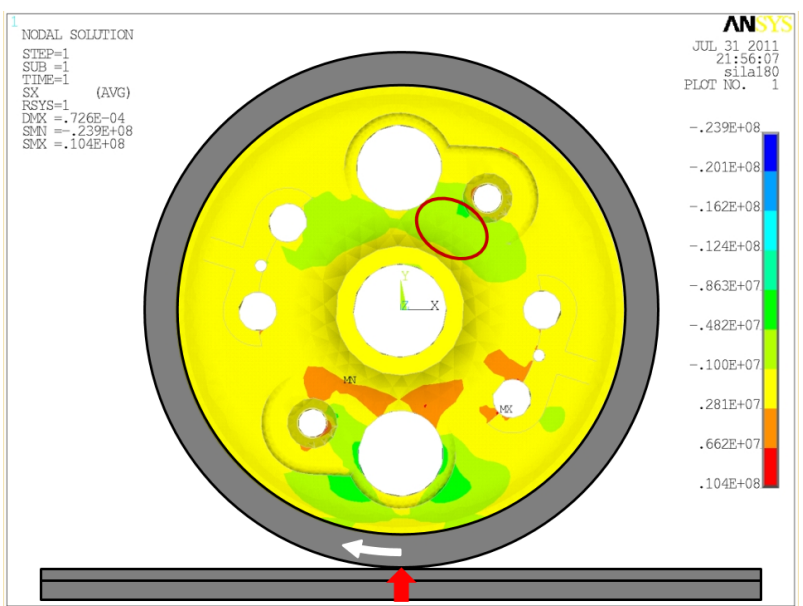

Rys.4. Przykładowe barwne mapy naprężeń w kierunku promieniowym w kole napędnym lokomotywy podczas toczenia się koła po szynie.

Wynikiem przeprowadzonej analizy wytrzymałościowej były między innymi barwne mapy naprężeń. Analiza map naprężeń pozwoliła wykazać, iż w obszarach koła, w których następuje pęknięcie, podczas toczenia się koła po szynie pojawiają się naprężenia o zmiennym znaku (rozciagające i ściskające). Poniżej przedstawiono wybrane, przykładowe mapy naprężeń promieniowych $\mathrm{w}$ kole dla różnych kątów obrotu koła względem szyny. $\mathrm{Na}$ rysunkach zaznaczono czerwoną elipsą miejsce powstawania pęknięć w obiekcie rzeczywistym. Położenie koła przedstawione na rysunku 4a (położenie odniesienia) oznaczono jako $0^{\circ}$. Rysunki przedstawiają rozkład naprężeń w tarczy koła z pominięciem obręczy. Rysunki 4a, 4b, 4c pozwalają zauważyć, że dla przykładowych kątów obrotu koła względem szyny $\left(0^{\circ}, 15^{\circ}, 30^{\circ}, \ldots\right)$ naprężenia promieniowe $\mathrm{w}$ miejscu pękania są rozciagające, natomiast dla wybranych przykładowych kątów obrotu koła względem szyny $\left(120^{\circ}, 135^{\circ}, \ldots 180^{\circ}\right.$, ...) naprężenia promieniowe $\mathrm{w}$ miejscu pękania są ściskające. Cykl taki powtarza się przy każdym obrocie koła względem szyny. 


\section{Badania własności magnetycznych materiału obiektu rzeczywistego}

Badania na obiekcie rzeczywistym przeprowadzono wykorzystując skopometr Fluke serii 190, miernik wielkości magnetycznych oraz sondy pomiarowe [2]. Badania na obiekcie rzeczywistym przeprowadzono na terenie ZNLE w Gliwicach, wykorzystując zezłomowane (z pęknięciem wykluczającym dalszą eksploatację) koło układu napędnego lokomotywy EU07. Pomiarów własności magnetycznych materiału koła dokonano wzdłuż czternastu wybranych promieni koła w ośmiu punktach na każdym z wybranych promieni (ścieżek pomiarowych). Ścieżki pomiarowe wybrano w taki sposób, aby przebiegały one przez miejsca $\mathrm{w}$ bezpośrednim sąsiedztwie miejsca pęknięcia koła jak i przez miejsca niewykazujące oznak początków utraty ciągłości (rys.5.).

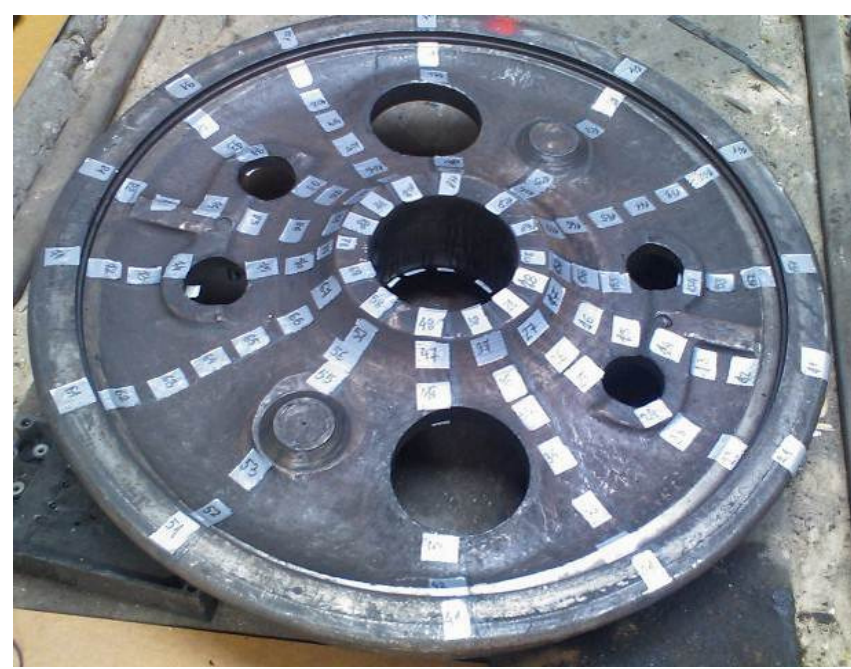

Rys.5. Koło napędne lokomotywy EU07 z zaznaczonymi miejscami pęknięć.

Dokonano pomiarów dynamicznej pętli histerezy magnetycznej. Na każdą ze zmierzonych pętli histerezy składały się cztery pełne jej przebiegi. Badania oparte były na zasadzie pomiaru wartości indukcji magnetycznej w szczelinie powietrznej obwodu magnetycznego, w którym jarzmo z uzwojeniem magnesuje badany materiał [7]. Do pomiaru wartości indukcji magnetycznej (wyrażonej wartością napięcia) wykorzystano hallotron. Zworą w układzie magnesującym był badany obiekt (ograniczony obszar koła kolejowego). Zarejestrowane przebiegi napięć $u_{1}$ i $u_{2}$ (na wejściu i wyjściu sondy pomiarowej) pozwoliły na wykreślenie dynamicznej pętli histerezy magnetycznej. Zmierzona wartość napięcia $u_{1}$ na wejściu sondy pomiarowej była proporcjonalna do wartości natężenia pola magnetycznego $\mathrm{w}$ obwodzie $\left(u_{1}[V]=f(H[A / m])\right)$. Zmierzona wartość napięcia $u_{2}$ na wyjściu sondy pomiarowej była proporcjonalna do wartości indukcji magnetycznej w szczelinie powietrznej układu magnesującego $\left(u_{2}[V]=f(B[T])\right)$. Dynamiczne pętle histerezy magnetycznej zostały wyznaczone przy magnesowaniu materiału w zakresie średnich pól magnesujących.

Wyniki pomiarów wartości napięcia $u_{l}$ - parametru proporcjonalnego do wartości natężenia koercji $H_{c}$ przedstawiono na wykresie kołowym (rys.6.). Pomijając obręcz koła, na której zaobserwowano największe wartości parametru natężenia koercji, najprawdopodobniej spowodowane zmianami w materiale od długotrwałego działania karbu (podtoczenia) znajdującego się tuż obok obręczy, największe wartości parametru $H_{c}$ w tarczy koła zaobserwowano w miejscach odpowiadających miejscom, w których najczęściej następują pęknięcia (por. rys.2. i rys.6.).

Wyniki pomiarów wartości napięcia $u_{2}$ - parametru proporcjonalnego do maksymalnej wartości wektora indukcji magnetycznej B przedstawiono na wykresie kołowym (rys.7.). Pomijając obręcz koła, na której zaobserwowano największe wartości parametru indukcji, najprawdopodobniej spowodowane zmianami $\mathrm{w}$ materiale od długotrwałego działania karbu (podtoczenia) znajdującego się tuż obok obręczy, największe wartości parametru $B \mathrm{w}$ tarczy koła zaobserwowano w miejscach odpowiadających miejscom, w których najczęściej następują pęknięcia (por. rys.2. i rys.7.).

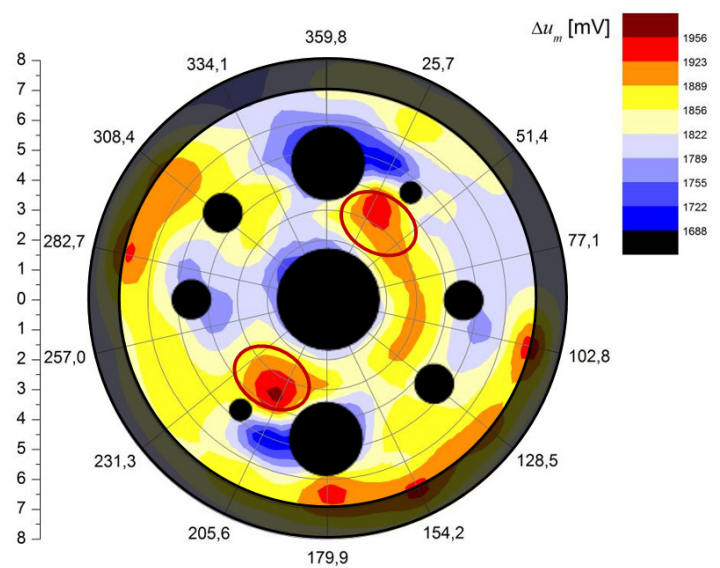

Rys.6. Mapa rozkładu parametru natężenia koercji $H_{c}$ na powierzchni wewnętrznej badanego koła $\mathrm{z}$ zaznaczonymi miejscami powstawania pęknięć na obiekcie rzeczywistym.

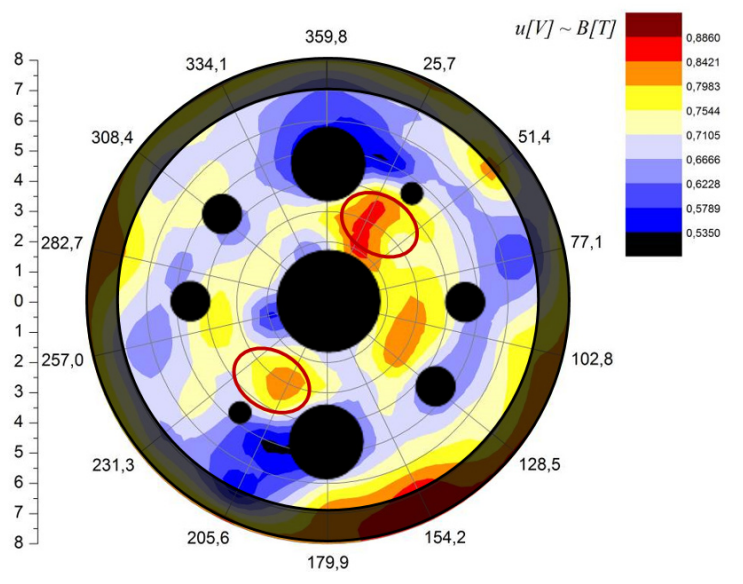

Rys.7. Mapa rozkładu parametru indukcji magnetycznej $B$ na powierzchni wewnętrznej badanego koła z zaznaczonymi miejscami powstawania pęknięć na obiekcie rzeczywistym. 
Kolejnym badaniem magnetycznym materiału koła było badanie $\mathrm{z}$ wykorzystaniem sondy działającej na zasadzie sondy Foerstera [8]. Pomiary wykazały wpływ badanego materiału koła (materiał o mniejszym lub większym stopniu degradacji zmęczeniowej) na wartość indukcyjności $L_{2}$, a tym samym na wartość mierzonego napięcia $u_{m}$. Układ pomiarowy wyskalowano tak, aby wskazywał on jedynie zmiane napięcia $u_{m}$ czyli $\Delta u_{m}$. Pomiary $\Delta u_{m}$ w punktach siatki pomiarowej na wewnętrznej $\mathrm{i}$ zewnętrznej powierzchni koła pozwoliły na wykreślenie barwnej mapy rozkładu wartości $\Delta u_{m}$ na powierzchniach bocznych koła napędnego (rys.8.).

Największe wartości napięcia $\Delta u_{m}$, w tarczy koła zaobserwowano w miejscach odpowiadających miejscom, w których najczęściej następują pęknięcia (por. rys.2. i rys.8.). Duże wartości $\Delta u_{m}$ zaobserwowano również w obręczy koła najprawdopodobniej spowodowane zmianami $\mathrm{w}$ materiale od długotrwałego działania karbu (podtoczenia) znajdującego się tuż obok obręczy.

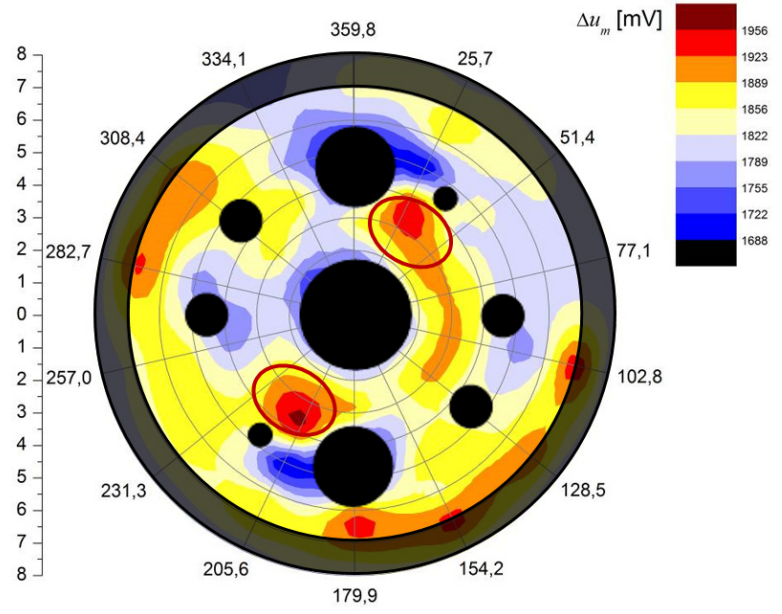

Rys.8. Mapa rozkładu wartości $\Delta u_{m}$ na powierzchni wewnętrznej badanego koła z zaznaczonymi miejscami powstawania pęknięć na obiekcie rzeczywistym.

\section{Wybrane wyniki badań laboratoryjnych}

Pomiary laboratoryjne przeprowadzono wykorzystując próbki materiału wycięte $\mathrm{z}$ badanego koła. Próbki wycięto z miejsc bezpośrednio sąsiadujących z miejscem pęknięcia (próbki o większym stopniu degradacji zmęczeniowej - oznaczone jako WSD) jak i z miejsca oddalonego od pęknięcia w kole (próbki o mniejszym stopniu degradacji zmęczeniowej - oznaczone jako MSD). Wykorzystany do badań miernik własności fizycznych PPMS (Physical Property Measurement System) pozwolił między innymi na wyznaczenie krzywych pierwotnego magnesowania (rys.9.). Zaobserwowano mierzalne różnice w charakterze krzywych pierwotnego magnesowania próbek o mniejszym i większym stopniu degradacji zmęczeniowej materiału, przejawiające się wyraźną różnica poziomów nasycenia magnetycznego. Dokonano równiwż pomiarów krzywych pier- wotnego magnesowania za pomocą stanowiska laboratoryjnego skonstruowanego w Katedrze Transportu Szynowego.

\section{Wnioski z badań}

Przeprowadzone badania własności magnetycznych (pętle histerezy magnetycznej, natężenie koercji, krzywa pierwotnego magnesowania) materiału koła napędnego lokomotywy EU07 wskazują na istnienie mierzalnych różnic ich wartości w zależności od stopnia zmęczeniowej degradacji materiału koła. Miejsca największej degradacji zmęczeniowej cechuje największa wartość natężenia koercji (rys.6), największa wartość indukcji magnetycznej (rys.7) oraz największa wartość zmian indukcyjności (rys.8). Badania laboratoryjne krzywych pierwotnego magnesowania materiału próbek wykazały, iż materiał z obszarów o mniejszym stopniu degradacji zmęczeniowej cechuje wyższy poziom magnetyzacji nasycenia w odniesieniu do próbek materiału o wyższym poziomie degradacji zmęczeniowej (rys.9).

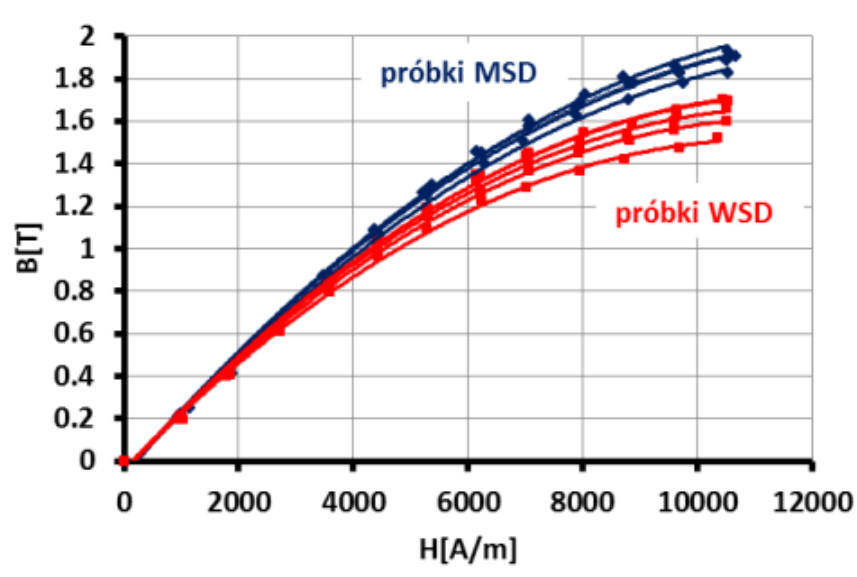

Rys.9. Krzywe pierwotnego magnesowania próbek o większym stopniu degradacji zmęczeniowej (WSD) i o mniejszym stopniu degradacji zmęczeniowej (MSD).

Wyniki badań eksperymentalnych oraz analiza literaturowa wskazują na możliwość zastosowania zaproponowanej metody pomiaru stopnia degradacji zmęczeniowej materiału $\mathrm{w}$ diagnostyce kolejowych zestawów kołowych.

\section{Literatura}

[1] Bizoń K.: Symulacyjna ocean obciqżeń zmęczeniowych $w$ tarczy koła napędnego zestawu kołowego, I Kongres Mechaniki Polskiej, 28-31 sierpnia 2007, Warszawa, wydawnictwo na $C D$.

[2] Żurek Z. H.: Opracowanie metody magnetycznej do wczesnej detekcji procesów zmęczeniowych w stalach niskostopowych i niskoweglowych. Rzadowy Projekt Badawczy Wtasny N N507 080733 (zakończony 15.11.2009, (K. Bizoń - główny wykonawca). 
[3] Bizoń k., Żurek Z. H.: Badania wytrzymałości zmęczeniowej stali stosowanej na zestawy kołowe $w$ oparciu o jej parametry magnetyczne, XIX Konferencja Naukowa Pojazdy Szynowe, Targanice k. Andrychowa, 15-17 września 2010, Materiały konferencyjne, tom I, strony 29-36.

[4] Żurek Z.H., Janeczek T., Maciejewski J.: Parametry magnetyczne stali jako kryterium diagnostyki zmęczeniowej. PAK, Pomiary Kontrola Automatyka, 9/2008, strony 670-673.

[5] Żurek Z.H., Czqstkiewicz Z.: Pomiary magnetyczne stali paramagnetycznych. PAK, Pomiary Kontrola Automatyka, IV/2009, 229-232.
[6] Fleischer B.: Notfallmanagement und verhalten im notfall, DZB 4, Mannheim Deine Bahn 9/2000, s.560-564

[7] Sitarz M., Sładkowski A., Chruzik K.: Metody numeryczne $w$ projektowaniu kót kolejowych zestawów kołowych. Monografia. Katowice 2003.

[8] Bizoń K.: Wykrywanie stref wplywu procesów zmęczeniowych $w$ tarczy koła napędnego lokomotywy EU07 metodami magneto-indukcyjnymi. 40 Krajowa Konferencja Badań Nieniszczacych, referat $n r$ R08, wydawnictwo na $C D$. 